\title{
Pesan Kesetaraan Gender Dalam Pidato Emma Watson di PBB Tahun 2014
}

\author{
Rio Saputra Ambarita \\ London School of Public Relations, Jakarta, Indonesia \\ Email: riosaputraam@gmail.com
}

\begin{abstract}
This study analyzes a text of the speech that was delivered by Emma Watson as the UN Ambassador to women at the opening of the \#HeForShe campaign in New York, United States. This is based on an interest in the issue of gender equality and feminism which is still a widespread concern to date. Emma Watson voiced her speech on gender equality so that women get the same rights as men in various sectors. The method used in this study is a qualitative method using the Feminism and Gender approach. The researcher analyzed the text of the speech of the official website of UN Women using the Discourse Feminism Analysis method by Sara Mills. The results of the study show that there is a construction of the meaning and identity of a woman in Emma Watson's speech text which is displayed by the choice of language in the speech by the dominant party. In the text of the speech delivered by Emma Watson, she wanted to create a unity between women and men so that they could walk together, and support each other to create peace so that they would not demean the other party and no one felt humiliated.
\end{abstract}

Key words: Feminism, Gender, Discourse Analysis.

\begin{abstract}
Abstrak
Penelitian ini menganalisis tentang teks pidato yang dibawakan oleh Emma Watson sebagai Duta PBB untuk perempuan pada pembukaan kampanye \#HeForShe di New York, Amerika Serikat. Hal ini dilandasi oleh ketertarikan pada isu kesetaraan gender dan feminisme yang masih menjadi perhatian luas sampai saat ini. Emma Watson menyuarakan pidatonya tentang kesetaraan gender agar perempuan mendapatkan hak yang sama seperti dengan laki-laki di dalam berbagai sektor. Metode yang digunakan dalam penelitian ini adalah metode kualitatif dengan menggunakan pendekatan feminisme dan gender. Peneliti menganalisis teks pidato yang diambil dari website resmi PBB untuk perempuan dengan menggunakan metode analisis wacana feminisme oleh Sara Mills. Hasil penelitian menunjukkan bahwa terdapat konstruksi makna dan identitas seorang perempuan dalam teks pidato Emma Watson yang ditampilkan dengan pemilihan bahasa pada pidato tersebut oleh pihak dominan. Dalam teks pidato yang dibawakan oleh Emma Watson ingin menciptakan kesatuan antara perempuan dan laki-laki sehingga dapat berjalan bersama, dan saling mendukung satu sama lain untuk membuat kedamaian sehingga tidak merendahkan pihak lainnya dan tidak ada yang merasa terendahkan.
\end{abstract}

Kata kunci: Feminisme, Gender, Analisis Wacana. 


\section{Latar Belakang Permasalahan}

Gender merupakan konsep pengklasifikasian sifat perempuan (feminim) dan laki-laki (maskulin) yang merupakan hasil konstruksi secara sosial budaya, sehingga dapat dipertukarkan dan berbeda antara satu budaya dengan budaya lainnya. Gender merupakan harapanharapan budaya terhadap perempuan dan laki-laki, tidak bersifat universal dan tidak bersifat permanen sehingga dapat berubah dari waktu ke waktu. Dengan kata lain, konsep gender adalah konsep budaya yang berupaya membuat perbedaan dalam hal peran, posisi, perilaku, mentalis dan karakteristik emosional antara perempuan dan laki-laki dalam suatu masyarakat (Iswary, 2010).

Kesetaraan antara laki-laki dan perempuan atau lebih dikenal dengan istilah kesetaraan gender telah menjadi pembicaraan yang hangat akhir-akhir ini. Melalui perjalanan panjang untuk mayakinkan dunia bahwa perempuan telah mengalami diskriminasi hanya karena perbedaan jenis kelamin dan perbedaan secara sosial, akhirnya pada tahun 1979, Perserikatan Bangsa-Bangsa (PBB) menyetujui konferensi mengenai penghapusan segala bentuk diskriminasi terhadap perempuan. Konferensi ini sebenarnya telah diratifikasi oleh Indonesia pada tahun 1984 menjadi UU No. 7/1984, tetapi jarang disosialisasikan dengan baik oleh negara. Konferensi maupun UndangUndang tersebut pada kenyataannya tidak juga sanggup menghapus diskriminasi yang dialami oleh perempuan. Diseluruh dunia masih ada perempuan yang mengalami segala bentuk kekerasan seperti: kekerasan fisik, mental, sosial dan ekonomi; baik di rumah, di tempat kerja maupun di masyarakat (Hermawati, 2007).

Contoh kasus berkaitan dengan bentuk kekerasan misalnya saja, seorang perempuan, istri anggota DPRRI yang dengan tegar mensupport suami yang terindikasi melakukan perselingkuhan. Nampak sekali adanya ketidakadilan di sini. Laki-laki dengan seenaknya berbuat salah, sementara pihak perempuan dengan segala kelemahannya, dengan alasan keutuhan keluarga, kasihan anak-anak dan lain-lain tetap menerima adanya penindasan batin dari laki-laki (Hermawati, 2007).

Kasus lainnya yakni seorang istri dari seorang da'i kondang yang rela dimadu serta mendukung suami dalam melakukan poligami. Dengan dalih dan alasan apapun, ketidakadilan nampak jelas di sini. Di sini kita tidak sedang mempersalahkan boleh atau tidaknya berpoligami, tetapi lebih kepada perlakuan tidak adil terhadap perempuan. Ironis 
sekali, disaat kesetaraan gender sedang diperjuangkan, tingkah polah laki-laki yang merupakan tokoh masyarakat, sangat menginjak-injak harga diri perempuan. Walaupun di berbagai media, para istri tersebut tegar, namun dari raut muka, penuturan kata-kata yang diucapkan jelas terasa bahwa perempuan tersebut mengalami dan merasakan adanya ketidakadilan (Hermawati, 2007).

Kurangnya kesadaran masyarakat akan kesetaraan gender membuat perempuan masih merasa dipandang lemah dan tidak dapat melakukan banyak hal, dan tidak dipungkiri hal ini masih terjadi. Isu kesetaraan gender muncul dikarenakan perempuan masih memiliki kesempatan terbatas dibandingkan dengan laki-laki untuk berperan aktif dalam berbagai program dan aktifitas lainnya di masyarakat, seperti kegiatan ekonomi, sosial-budaya, pendidikan, organisasi dalam kelembagaan, dan sebagainya. Keterbatasan ini berasal dari berbagai nilai dan norma yang ada di masyarakat, yang membatasi ruang gerak perempuan dibandingkan dengan laki-laki. Oleh karena itu, perempuan masih menganggap bahwa permasalahan yang tidak kunjung selesai juga karena masih terjadi dan ada di lingkungan sekitar dan beberapa orang akhirnya menyebut diri mereka adalah seorang 'feminist' untuk memperjuangkan hak-hak nya. Salah satu orang yang menyuarakan gerakan 'feminist' adalah Simone de Beauvoir, Eleanor Roosevelt, Marlene Dietrich, Betty Friedan, Gloria Steinem dan Angela Davis (Fisher, 2018).

Secara etimologis feminis berasal dari bahasa Prancis, yaitu femme (woman) yang berarti perempuan (tunggal) yang berjuang untuk memperjuangkan hak-hak kaum perempuan (jamak), sebagai kelas sosial. Dalam pengertian yang paling luas feminis, adalah gerakan kaum perempuan untuk menolak segala sesuatu yang dimarginalisasikan, disubordinasikan, dan direndahkan oleh kebudayaan dominan, baik dalam bidang politik, ekonomi, dan kehidupan sosial pada umumnya (Sandy, 2014). Dampak feminisme memang nyata dimana dalam waktu 20 tahun banyak terjadi perubahan dan perkembangan yang menyangkut nasib kaum perempuan. Setelah pada tahun 1975 PBB mengumumkan International Decade of Women, terjadi beberapa peristiwa penting bagi kaum perempuan. tahun 1979 PBB mengeluarkan resolusi untuk menghentikan segala bentuk diskriminasi terhadap perempuan. Kini, hampir setiap negara memiliki undang-undangan anti diskriminasi, yang menguntungkan kaum perempuan terutama bagi perempuan kelas menengah dan yang berpendidikan. Tak lama kemudian jumlah anak perempuan 
yang sekolah meningkat; kontrol mereka atas berapa anak yang dikehendaki serta pilihan kontrasepsi juga menguat. Pornografi seksisme dalam bahasa juga mendapat tantangan, meskipun belum sepenuhnya berhasil. Revolusi di Zimbabwe, Anggola, Mozambique dan Nicaragua memasukan pembebasan perempuan sebagai bagian dalam ideology mereka. Bahkan hampir sebagian universitas besar kini membuka bidang Women Study. Bidang dan biro urusan perempuan sudah dibentuk di hampir setiap organisasi internasional maupun lokal (Fakih, 2013).

Berkaitan dengan hal tersebut di atas maka diperlukan gerakan kesetaraan gender agar dapat mengedukasi banyak orang sehingga semakin banyak yang mengetahui tentang permasalan ini, mengerti banyak perempuan yang menyadari haknya dan dapat memperjuangkannya.

Ada beberapa klasifikasi dan teoriteori feminisme, ssalah satunya adalah yang dikembangkan oleh Rosemarie Putnan Tong. Dia mengembangkan keragaman pemikiran feminis yang terdiri dari feminisme liberal, feminisme radikal, feminisme marxis, feminisme sosialis, feminisme psikoanalisis, feminisme gender, feminisme eksistensialis, feminisme postmodern, feminisme multikultural, feminisme global dan ekofeminisme. Feminisme kultural lebih berkaitan dengan peningkatan nilai-nilai perempuan ketimbang menjelaskan usulusulnya. Argument perbedaan gender yang kekal ini pertama kali dipakai untuk melawan perempuan dalam diskursus patriarkis laki-laki untuk mengklaim bahwa perempuan adalah inferior dan tunduk pada laki-laki. Pada teoritis seperti Margaret Fuller, Frances Willard, Jane Addams, dan Charlotte Perkins Gilman merupakan proponen feminisme kultural yang mengatakan bahwa dalam mengatur negara, masyarakat memerlukan nilai-nilai perempuan seperti kerja sama, perhatian, pasifisme, dan penyelesaian konflik tanpa menggunakan kekerasan (Ritzer \& Goodman: 2008).

Meskipun feminisme sebagai gerakan sudah tua, namun baru tahun 60an dianggap sebagai lahirnya gerakan itu. Gerakan feminisme tersebut muncul di Amerika sebagai bagian dari kultur radikal termasuk gerakan hak-hak sipil (civil right) dan kebebasan seksual (sexual liberation). Buku Betty Friedan, The Feminist Mystique (1963) laku keras, dan setelah itu tumbuh berkembang kelompok feminis yang memperjuangkan kaum perempuan guna memenuhi kebutuhan praktis seperti pengasuhan anak (childcare), kesehatan pendidikan, aborsi dan lain sebagainya. 
Lantas gerakan itu merambat ke Eropa, Kanada dan Australia yang selanjutnya kini telah menjadi gerakan global dan menggoncang Dunia Ketiga (Fakih, 2013).

Secara kuantitatif, dampak feminisme memang nyata dimana dalam waktu 20 tahun banyak terjadi perubahan dan perkembangan yang menyangkut nasib kaum perempuan. Setelah pada tahun 1979 PBB mengumumkan International Decade of Women, terjadi beberapa peristiwa penting bagi kaum perempuan. Tahun 1978 PBB mengeluarkan resolusi untuk menghentikan segala bentuk diskriminasi terhadap perempuan. Kini hampir semua negara memiliki perundang-undangan anti diskriminasi yang menguntungkan kaum perempuan terutama bagi perempuan kelas menengah dan yang berpendidikan. Tak lama kemudia jumlah perempuan yang sekolah meningkat, kontrol mereka atas berapa banyak anak yang dikehendaki serta pilihan kontrasepsi junga menguat (Fakih, 2013)

Pidato termasuk keterampilan berbicara (dalam Rakhmad, 2011, p.89134) menyebutkan tiga tujuan pidato, yaitu pidato informatif, pidato persuasif, dan pidato rekreatif. Dalam berpidato, pesan yang disampaikan oleh pembicara harus dipahami oleh pendengar. Bahasa yang digunakan oleh pembicara kepada pendengar harus jelas agar tidak terjadi salah pengertian diantara keduanya. Hal tersebut dilakukan agar pesan yang disampaikan sama dengan yang diterima pendengar.

Terdapat beberapa cara dalam menyampaikan pidato, seperti pidato yang dilakukan dengan menghafal teks, pidato yang dilakukan tanpa persiapan atau spontan, sampai pidato yang dilakukan dengan membaca naskah atau teks pidato dari awal sampai akhir yang disebut Manuskrip. "Manuskrip diperlukan oleh tokoh nasional, sebab kesalahan satu kata saja dapat menimbulkan kekacauan dan berakibat jelek bagi pembicara" (Rakhmat, 2002, p.18) dapat dikatakan pidato merupakan faktor yang penting untuk situasi formal atau dalam acara penting dan sakral. Seperti pidato yang disampaikan oleh bupati, gubernur, presiden, atau tokoh masyarakat lainnya. Seperti dalam penelitian ini yang menfokuskan pada pidato yang disampaikan oleh Emma Watson di Markas besar PBB New York pada Sabtu, 20 September 2014 mengenai kesetaraan gender. Pidato tersebut sekaligus dilakukan dalam peluncuran kampanye "HeForShe" Saat ini Emma Watson juga menjadi duta PBB untuk kesetaraan gender.

Emma Watson melihat bahwa perempuan dan laki- laki semestinya mempunyai hak yang sama. Emma 
Watson juga mengajak semua lapisan masyarakat agar dapat mendukung gerakan "HeForShe" serta dapat melangkah maju dan berani. Hal inilah yang membuat Emma Watson berpikir bahwa laki-laki dan perempuan memiliki hak dan kesempatan yang sama.

Dalam acara PBB tersebut, Emma Watson menyampaikan pidato penuh semangat tentang jalan yang ditempuhnya menuju feminisme dan perlunya mengubah cap negatif yang diberikan pada feminis sebagai sosok pembenci laki-laki. Teks Pidato Emma Watson yang menjadi topik penelitian ini telah di unggah di website resmi PBB untuk wanita.

Berdasarkan uraian di atas maka penelitian mengenai pesan kesetaraan gender pada teks pidato Emma Watson menjadi suatu hal yang menarik untuk diteliti.

\section{Metode Penelitian}

Penelitian ini menggunakan metode penelitian Kualitatif yang bersifat deskriptif dengan menggunakan analisis. Teknik pengumpulan data menggunakan dokumen berupa teks resmi yang di bawakan oleh Emma Watson yang diunggah di website resmi milik PBB untuk Perempuan. Data yang diperoleh dianalisis menggunakan analisis wacana kritis Sara Mills yang disebut sebagai perspektif Feminis. Titik perhatian dari persepektif wacana feminis adalah menunjukan bagaimana teks bias dalam menampilkan wanita sebagai objek pemberitaan. Titik perhatian dari analisis wacana adalah menunjukan bagaimana wanita digambarkan dan dimarjinalkan dalam teks berita, dan bagaimana bentuk dan pola pemarjinalan itu dilakukan. Ini tentu saja melibatkan strategi wacana tertentu sehingga ketika ditampilkan dalam teks, wanita tergambar secara buruk (Eriyanto, 2001).

\section{Hasil Penelitian}

\section{Posisi Subjek}

Subjek dalam pidato Emma Watson di PBB ini adalah Emma Watson dan kaum perempuan. Emma Watson dan kaum perempuan digambarkan pada pidato ini sedang menceritakan mengenai peluncuran kampanye HeForShe yang bertujuan untuk mengakhiri ketidaksetaraan gender. Emma Watson menginginkan kesetaraan gender antara laki-laki - perempuan, dan ingin menghentikan ketidaksetaraan gender yang sedang terjadi di masa kini. Seperti dalam pernyataan sebagai berikut:

"Semakin saya sadar bahwa
memperjuangkan hak-hak perempuan
menjadi identik dengan membenci pria.
Jika ada satu hal yang saya tahu pasti, ini
harus dihentikan. Sebagai catatan,
feminisme menurut definisi adalah
Keyakinan bahwa pria dan wanita harus


memiliki hak dan peluang yang sama." (UN WOMEN, 2014).

Emma Watson sebagai Subjek, menginginkan kesetaraan gender. Semua ini bermula karena Emma merasa dari kecil mengalami ketidakadilan gender. Emma Watson sebagai subjek merasa bahwa dia tidak mendapatkan hak yang sama dengan laki-laki. Seperti dalam pernyataan berikut:

"Saya pikir itu benar bahwa saya harus dapat membuat keputusan tentang tubuh saya sendiri. Saya pikir benar bahwa perempuan terlibat atas nama saya dalam kebijakan dan pengambilan keputusan di negara saya. Saya pikir memang benar bahwa secara sosial saya diberikan rasa hormat yang sama dengan pria." (UN WOMEN, 2014).

Emma Watson juga menginginkan laki-laki untuk ikut berpartisipasi dan bergabung demi terciptanya kesetaraan gender. Seperti dalam pernyataan berikut:

"Para pria - saya ingin mengambil kesempatan ini untuk menyampaikan undangan resmi Anda. Kesetaraan gender juga menjadi masalah Anda. Karena sampai saat ini, saya telah melihat peran ayah saya sebagai orang tua yang kurang dihargai oleh masyarakat meskipun saya membutuhkan kehadirannya sebagai anak seperti halnya ibu saya." (UN WOMEN, 2014).

Subjek merasa bahwa lelaki dan perempuan, seharusnya merasa bebas dan setara. Seperti dalam pernyataan berikut:

"Baik pria maupun wanita harus merasa bebas untuk menjadi sensitif. Baik pria maupun wanita harus merasa bebas untuk menjadi kuat... Sudah saatnya kita semua memandang gender dalam spektrum bukan sebagai dua perangkat ideal yang saling bertentangan." (UN WOMEN, 2014).

\section{Posisi Objek}

Objek dalam pidato Emma Watson di PBB ini adalah laki-laki. Laki-laki dalam konteks pidato ini juga terkena dampak dari ketidaksetaran gender. Seperti dalam pernyataan berikut:

"Saya melihat laki-laki yang menderita
penyakit mental dan tidak dapat meminta
bantuan karena takut itu akan membuat
mereka terlihat kurang "macho" _bahkan
di Inggris bunuh diri terbanyak antara
usia 20-49 tahun; melebihi kecelakaan
lalu lintas, kanker dan penyakit jantung
koroner. Saya juga melihat laki-laki dibuat
rapuh dan rasa tidak nyaman oleh
perasaan terdistorsi tentang apa yang
merupakan keberhasilan laki-laki. Laki-
laki juga tidak merasakan manfaat
kesetaraan." (UN WOMEN, 2014).

Pidato ini mengarah kepada lakilaki yang diminta untuk dapat melakukan perubahan. Emma Watson juga menekankan bahwa seharusnya para pria mendukung gerakan ini. Seperti dalam pernyataan berikut:

\footnotetext{
"Para pria - saya ingin mengambil kesempatan ini untuk menyampaikan undangan resmi Anda. Kesetaraan gender juga menjadi masalah Anda. Karena sampai saat ini, saya telah melihat peran ayah saya sebagai orang tua yang kurang dihargai oleh masyarakat meskipun saya membutuhkan kehadirannya sebagai anak seperti halnya ibu saya." (UN WOMEN, 2014).
}

\section{Pemaparan mengenai Subjek-Objek.}

Semua lapisan masyarakat sebagai subjek-objek baik pria maupun wanita memiliki hak dan kesempatan yang sama.

Namun untuk menghasilkan kesetaraan gender dibutuhkan laki-laki sebagai pihak yang dominan untuk dapat 
mewujudkannya, dan jika laki-laki dan perempuan dapat bekerja sama, maka tidak mustahil kesetaraan gender akan terjadi. Jika melihat dari Subjek-Objek keduanya memiliki kesempatan untuk menampilkan dirinya sendiri. Namun dapat dilihat bahwa yang dominan adalah laki-laki sebagai pendorong perubahan untuk terciptanya kesetaraan gender laki-laki dan perempuan.

\section{Posisi Pembaca}

Posisi Pembaca pada pidato yang terdekat adalah anggota PBB karena pidato tersebut dibacakan di forum PBB selain itu Pidato juga ditujukan kepada semua masyarakat dunia, termasuk kaum laki-laki serta kaum perempuan. Namun lebih ditujukan untuk kaum laki-laki agar dapat membantu feminisme.

Dalam pidato, Emma Watson menujukan kepada anggota PBB, yang mayoritas adalah perempuan yang menghadiri pertemuan saat itu, pidato juga ditujukan kepada kaum laki-laki dan perempuan agar dapat mewujudkan kesetaraan gender yang adil untuk segala lapisan. Emma Watson sangat menginginkan untuk kaum laki-laki agar dapat mendukung kampanye nya untuk menghapuskan ketidaksetaraan gender ini. Karena ketidakadilan gender bukan hanya terjadi kepada perempuan saja, tetapi juga terjadi kepada laki-laki. Dan oleh sebab itu jika laki-laki menyadari akan ketidaksetaraan gender ini diharapkan agar dapat mewujudkan kesetaraan gender yang adil untuk semua lapisan dan dapat mendapatkan hak-haknya agar bisa mengekpresikan dirinya secara lebih bebas.

Pidato ini juga ditujukan kepada kaum perempuan untuk ikut bergabung dan ikut berkontribusi untuk kesetaraan gender, agar perempuan mendapatkan hak yang sama dengan laki-laki dalam segala bidang, agar perempuan dapat ikut berpartisipasi dalam politik, ekonomi dan sosial. Membuktikan bahwa perempuan juga mempunyai hak yang sama dan dapat melakukan hal yang laki-laki lakukan. Seperti dalam pernyataan berikut:

"Baik pria maupun wanita harus merasa bebas untuk menjadi sensitif. Baik pria maupun wanita harus merasa bebas untuk menjadi kuat... Sudah saatnya kita semua memandang gender dalam spektrum bukan sebagai dua perangkat ideal yang saling bertentangan.

Jika kita berhenti mendefinisikan satu sama lain dengan siapa diri kita dan mulai mendefinisikan diri kita sendiri dengan siapa diri kita - kita semua bisa lebih bebas dan inilah yang menjadi tujuan HeForShe. Ini tentang kebebasan." (UN WOMEN, 2014).

Bersama dengan PBB, Emma Watson memberikan kesadaran kepada perempuan dan laki-laki untuk menghentikan ketidaksetaraan gender. Sehingga laki-laki dan perempuan tidak terbebani dan dapat dengan bebas mengekpresikan dirinya. Perempuan dapat 
saja menjadi kuat dan laki-laki juga dapat menjadi sensitif, sehingga perempuan dan laki-laki dapat menjadi diri mereka sendiri.

Sara Mills banyak menulis mengenai teori wacana, akan tetapi titik perhatiannya terutama kepada wacana mengenai feminisme: bagaimana wanita ditampilkan di dalam teks, baik dalam novel, gambar, foto, ataupun dalam berita, oleh karena itu apa yang dilakukan oleh Sara Mills sering juga disebut sebagai perspektif feminis. Titik perhatian perspektif wacana feminis menunjukan bagaimana teks bias dalam menampilkan wanita. Wanita cenderung ditampilkan dalam teks sebagai pihak yang salah, marjinal dibandingkan dengan pihak lakilaki. Ketidakadilan dan penggambaran yang buruk mengenai wanita inilah yag menjadi sasaran utama dari tulisan Mills. Hal yang sama banyak terjadi dalam teks berita. Banyak berita menampilkan wanita sebagai objek pemberitaan. Berita mengenai perkosaan, pelecehan adalah sedikit dari berita-berita yang menampilkan wanita sebagai objek pemberitaan. Titik perhatian dari analisis wacana adalah menunjukan bagaimana wanita digambarkan dan dimarjinalkan dalam teks berita, dan bagaimana bentuk dan pola pemarjinalan itu dilakukan. Ini tentu saja melibatkan strategi wacana tertentu sehingga ketika ditampilkan dalam teks, wanita tergambar secara buruk (Eriyanto, 2001).

Perempuan masih di anggap the second class yang sering disebut sebagai "warga kelas dua" yang keberadaannya tidak begitu diperhitungkan. Implikasi dari konsep dan common sense tentang pemosisian yang tidak seimbang telah menjadi kekuatan di dalam pemisahan sektor kehidupam ke dalam sektor “domestik" dan sektor "publik" dimana perempuan dianggap orang yang berkiprah dalam sektor dosmestik sementara laki-laki ditempatkan dalam sektor publik. Ideologi semacam ini telah di sahkan oleh berbagai pranata dan lembaga sosial, yang ini kemudian menjadi fakta sosial tentang status dan peran yang dimainkan oleh perempuan (Abdullah, 1997).

Permasalahan gender sudah menjadi isu global yang sangat menarik perhatian dunia. Munculnya perhatian terhadap isu gender ini sejalan dengan pergeseran paradigma pembangunan dari pendekatan keamanan dan kestabilan menuju pendekatan kesejahteraan dan keadilan atau dari pendekatan produksi ke pendekatan kemanusiaan dalam suasana yang lebih demokratis dan terbuka. Terjadinya perubahan paradigma pembangunan seperti ini menjadi dasar untuk mengatasi persoalan ketidakadilan gender yang masih terjadi di masyarakat 
menuju terwujudnya Kesetaraan dan Keadilan gender (Arjani, 2008).

Dan untuk mewudkan kesetaraan gender yang adil, sudah pasti dibutuhkan dari segala pihak untuk ikut bekerja sama dan membantu untuk terciptanya kesetaraan gender yang hakiki, terutama dari kaum laki-laki yang menjadi faktor pendorong, maka dari itu diharapkan lakilaki dapat membantu dan menyuarakan kesetaraan gender, demi keadilan semua pihak agar perempuan dan laki-laki dapat berjalan bersama secara adil.

\section{Penutup}

Permasalahan gender yang diangkat oleh Emma Watson berfokus kepada hak perempuan yang ingin dicapai dan membuat perempuan dan laki-laki sejajar, tidak ada perbedaan di sektor ekonomi, politik dan sosial agar terciptanya kebebasan individu baik perempuan dan laki-laki. Dalam teks pidato yang dibawakan oleh Emma Watson yang berbicara mengenai feminisme dengan mengangkat isu gender didalamnya, hal ini bukan karena permasalahan feminisme untuk merebut hak-haknya dan membenci laki-laki namun karena ingin menyetarakan antara laki-laki dan perempuan sehingga mempunya kesempatan dan peluang yang sama dalam berbagai hal tanpa memandang lemah pihak tertentu.
Dalam teks pidato yang dibawakan oleh Emma Watson ingin menciptakan kesatuan antara perempuan dan laki-laki sehingga dapat berjalan bersama, dan saling mendukung satu sama lain untuk membuat kedamaian dan kebersamaan sehingga tidak merendahkan pihak lainnya dan tidak ada yang merasa terendahkan.

Kesetaraan gender adalah masalah bersama, dan tidak akan dapat terwujud tanpa campur tangan semua pihak, oleh dari itu untuk menciptakan kesetaraan gender dibutuhkan dukungan dari semua lapisan masyarakat dan pemerintahan, dari laki-laki dan perempuan. Dengan adanya dukungan dari semua pihak terutama dari kaum laki-laki, maka kesetaraan gender akan lebih mudah untuk diterima oleh orang banyak dan dapat terealisasikan kesetaraan gender yang adil untuk semua pihak, yaitu laki-laki dan perempuan, agar kaum laki-laki dan perempuan dapat saling membantu dan berjalan bersama dan saling mendukung satu sama lain. Dan direkomendasikan agar semua lapisan masyarakat dapat berpikir terbuka dan dapat menyuarakan dukungannya terhadap hak-hak perempuan yang seharusnya dimiliki, dan untuk tidak merendahkan suatu kaum hanya dari gender nya, agar terciptanya kehidupan yang adil dan lebih baik lagi. 


\section{Daftar Pustaka}

Arjani, Ni Luh. 2007. Kesetaraan dan Keadilan Gender (KKG) dan tantangan Global. Jurnal Ekonomi dan Sosial. Vol.1, No.2 Agustus 2008. Dapat diunduh dari: https://ojs.unud.ac.id/index.php/inp ut/article/view/3181

Eriyanto. 2001. Analisis Wacana Pengantar Analisis Teks Media. Yogyakarta: Lkis Yogyakarta.

Fakih, M. 2013. Analisis Gender \& Transformasi Sosial. Yogyakarta: Pustaka Pelajar.

Fisher, L. A. 2018, 3 8. 30 Inspiring Women Who Shaped Feminism. Diperoleh dari Harpers Bazzar: https://www.harpersbazaar.com/cul ture/features/g4201/famousfeminists-throughout-history/

Hermawati, T. 2007. Budaya Jawa dan Kesetaraan Gender. Jurnal

Komunikasi Massa. Vol 1, No 1 Juli 2007: 18-24. Dapat diunduh dari:

https://digilib.uns.ac.id/dokumen/de tail/10734/Budaya-Jawa-dan-

Kesetaraan-Gender

Irawan, Abdullah, 1997. Sangkan Paran Gender, Yogyakarta: Pustaka Pelajar

Iswary, Ery.(2010. Perempuan Makassar: Relasi Gender Dalam Folklor. Yogyakarta: Ombak.

Rakhmad, Jalaluddin. 2011. Retorika Modern: Suatu Pendekatan Praktis Bandung: PT. Remaja Rosdakarya

Ritzer, George \& Goodman, Douglas J. 2004. Teori Sosiologi Modern. Jakarta: Kencana.

Sandy, A. K. 2014. Wacana Feminisme Dalam Cerita Pendek Karya Djenar Maesa Ayu. Jurnal Ilmu
Komunikasi. Vol.2 No.1 Juni 2014: 46-47. Dapat diunduh dari: http://ojs.stikosaaws.ac.id/index.php/spektrum/articl e/viewFile/29/33

UN Women. 2014 Emma Watson : Gender equality is your issue too. [arikel ilmiah]. Dapat diunduh dari: https://www.unwomen.org/en/news /stories/2014/9/emma-watsongender-equality-is-your-issue-too 

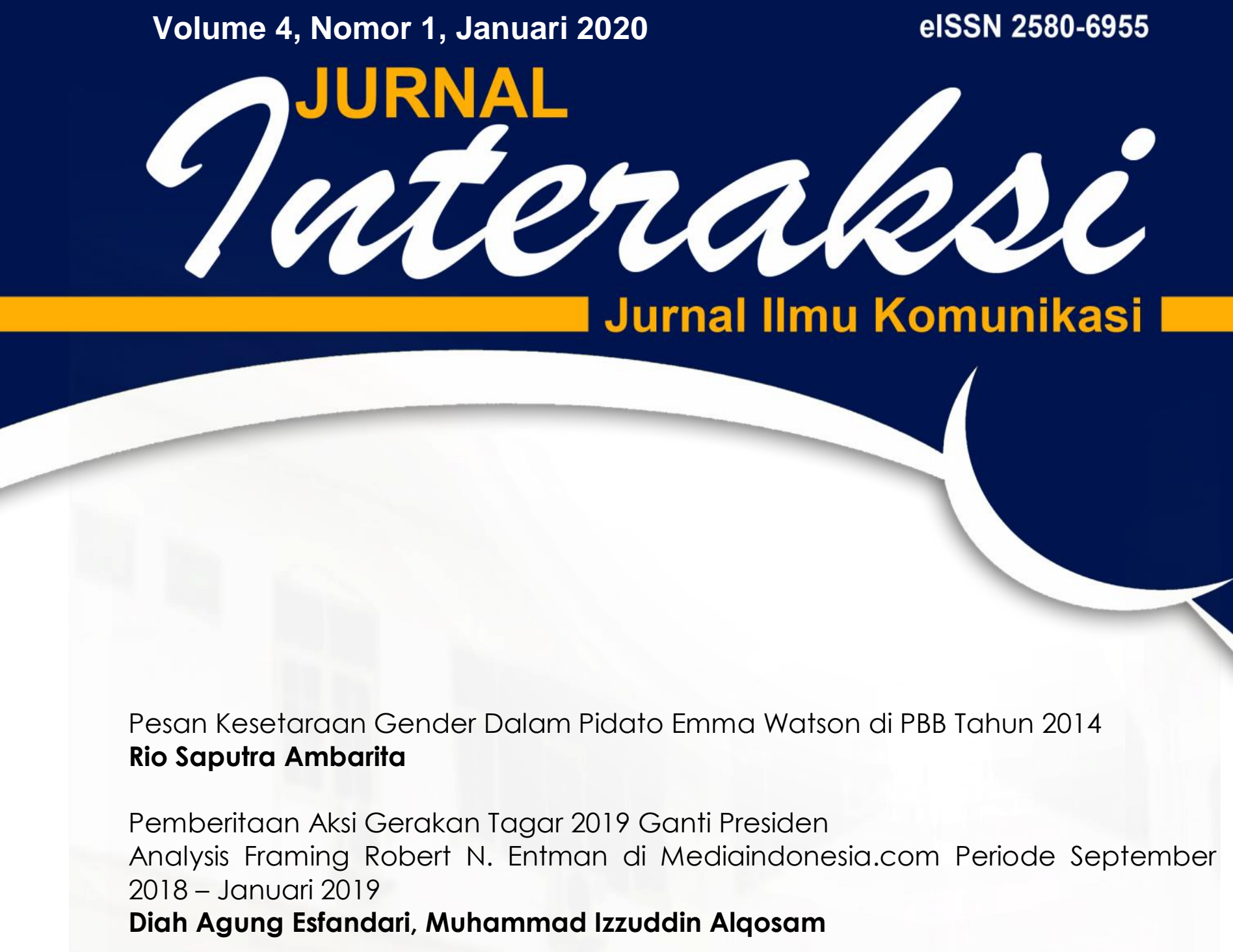

Branding Dan Positioning Identitas Budaya Indonesia Dalam Pesan Iklan TV Komersial Bejo Bintang Toedjoe Jahe Merah

Agus Hermanto, Sa'diah El Adawiyah

Identifikasi Faktor-Faktor Yang Mempengaruhi Minat Berkunjung Ke Olivier Café, Jakarta

\section{Tashia Tariq}

Studi Analisis Isi Pesan Dakwah Dalam Media Sosial Instagram @dakwah_tauhid Agus Triyono, Nifsya Khaira Marhuda

Relasi Politik, Bullying dan Etika Mengenai Isu "Muslim Uighur" di Media sosial Yofiendi Indah Indainanto

Breaking Down "Firewall" among Public Relations and Journalism Jamroji, Nasrullah

Strategi Komunikasi untuk Program Corporate Social Responsibility dalam Pemberdayaan Masyarakat

Arifin Saleh, Mislan Sihite 


\section{Turetralesi Jurnal IImu Komunikasi}

Jurnal Interaksi diterbitkan oleh Universitas Muhammadiyah Sumatera Utara (UMSU) bekerjasama dengan Asosiasi Pendidikan Ilmu Komunikasi Perguruan Tinggi Muhammadiyah (APIK PTM) yang terbit dua kali d alam setahun pada bulan Januari dan Juli. Terbit pertama kali pada bulan Januari 2017.

Jurnal Interaksi memuat tulisan yang difokuskan pada pemikiran kontemporer Ilmu Komunikasi, Media, Teknologi Komunikasi, Komunikasi Terapan, dalam berbagai sudut pandang atau perspektif. 


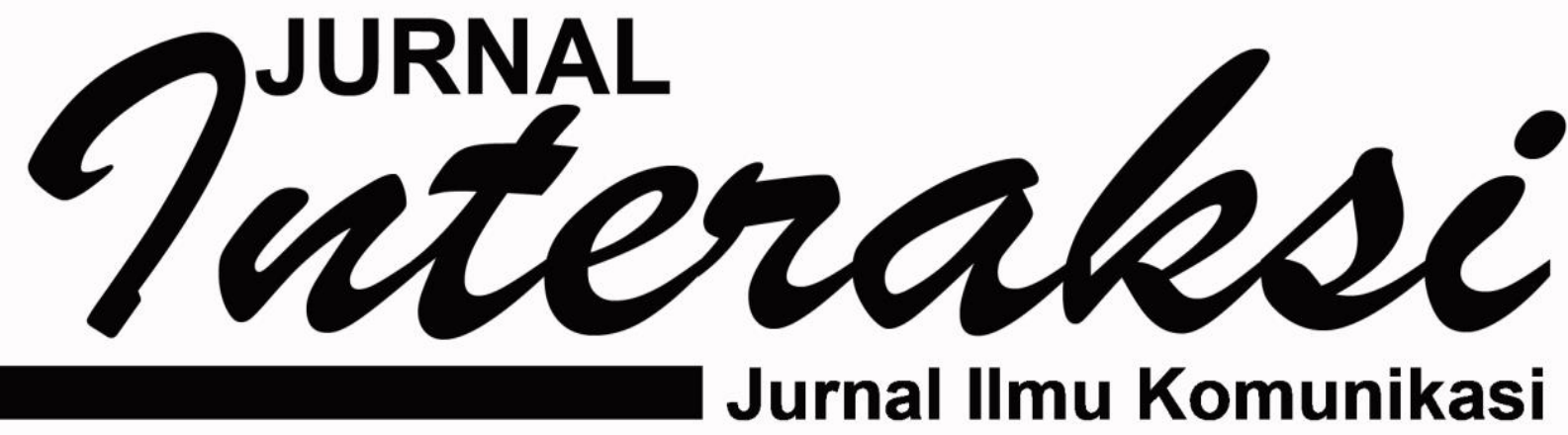

Pesan Kesetaraan Gender Dalam Pidato Emma Watson di PBB Tahun 2014 Rio Saputra Ambarita

Pemberitaan Aksi Gerakan Tagar 2019 Ganti Presiden

Analysis Framing Robert N. Entman di Mediaindonesia.com Periode September 2018 - Januari 2019

Diah Agung Esfandari, Muhammad Izzuddin Alqosam

Branding Dan Positioning Identitas Budaya Indonesia Dalam Pesan Iklan TV Komersial Bejo Bintang Toedjoe Jahe Merah

Agus Hermanto, Sa'diah El Adawiyah

Identifikasi Faktor-Faktor Yang Mempengaruhi Minat Berkunjung Ke Olivier Café, Jakarta

Tashia Tariq

Studi Analisis Isi Pesan Dakwah Dalam Media Sosial Instagram @dakwah_tauhid Agus Triyono, Nifsya Khaira Marhuda

Relasi Politik, Bullying dan Etika Mengenai Isu "Muslim Uighur" di Media sosial Yofiendi Indah Indainanto

Breaking Down "Firewall" among Public Relations and Journalism Jamroji, Nasrullah

Strategi Komunikasi untuk Program Corporate Social Responsibility dalam Pemberdayaan Masyarakat

Arifin Saleh, Mislan Sihite 


\section{Tuteralese}

Volume 4 Nomor 1 Edisi Januari 2020

\section{DAFTAR ISI}

\section{$1-11$}

Pesan Kesetaraan Gender Dalam Pidato Emma Watson di PBB Tahun 2014 Rio Saputra Ambarita

\section{$12-23$}

Pemberitaan Aksi Gerakan Tagar 2019 Ganti Presiden

Analysis Framing Robert N. Entman di Mediaindonesia.com Periode September 2018 - Januari 2019

\section{Diah Agung Esfandari, Muhammad Izzuddin Alqosam}

\section{4-40}

Branding Dan Positioning Identitas Budaya Indonesia Dalam Pesan Iklan TV Komersial Bejo Bintang Toedjoe Jahe Merah

Agus Hermanto, Sa'diah El Adawiyah

\section{1-49}

Identifikasi Faktor-Faktor Yang Mempengaruhi Minat Berkunjung Ke Olivier Café, Jakarta

\section{Tashia Taria}

\section{0-67}

Studi Analisis Isi Pesan Dakwah Dalam Media Sosial Instagram @dakwah_tauhid Agus Triyono, Nifsya Khaira Marhuda

\section{8-85}

Relasi Politik, Bullying dan Etika Mengenai Isu "Muslim Uighur" di Media sosial Yofiendi Indah Indainanto

\section{6-97}

Breaking Down "Firewall" among Public Relations and Journalism Jamroji, Nasrullah

98-105

Strategi Komunikasi untuk Program Corporate Social Responsibility dalam Pemberdayaan Masyarakat

Arifin Saleh, Mislan Sihite 